REvisTa TóPICOS EDUCACIONAIS

Revista do Programa de Pós-Graduação em Educação

da Universidade Federal de Pernambuco (UFPE)

\title{
ENTREVISTA COM PAULO DE MATTOS SKROMOV
}

\section{LINK: https://youtu.be/B g5chcMzw8}

\author{
Raphael Guazzelli Valerio ${ }^{1}$ \\ Universidade Federal de Pernambuco \\ André Campos de Camargo ${ }^{2}$ \\ Universidade Estadual de Campinas
}

\begin{abstract}
Nesta entrevista conversaremos com Paulo de Matos Skromov. Militante trotskista, sindicalista e membro fundador do Partido dos Trabalhadores (PT) em conjunto com figuras como Lula, Jacob Bittar, Olívio Dutra, Francisco Wefort, Chico de Oliveira, Eduardo Suplicy e Lelia Abramo em janeiro de 1980. No livro O sonho era possível, escrito pela pesquisadora chilena Marta Harnecker, Henos Amorina (1994, p. 12) informa-nos que "Paulo Skromov é uma verdadeira enciclopédia ambulante. Lembra-se de todos os fatos e de todas as datas. Pode passar três dias falando". Servir-nos-emos de sua privilegiada memória e de sua experiencia militante de esquerda para compreendermos as transformações capitalistas ocorridas no Brasil neste século. Esta entrevista se insere no projeto de maior envergadura que pretende, por um lado, rastrear as mudanças subjetivas de cunho político ocorridas na esquerda brasileira nestas últimas duas décadas e, por outro, criar subsídios que possam colaborar com a formação política de novos quadros para a transformação social da realidade contemporânea.
\end{abstract}

\section{Referências Bibliográficas}

HARNECKER, Marta. O sonho era possível: a história do Partido dos Trabalhadores narrada por seus protagonistas. São Paulo: Casa da América Livre, 1994.

LAZZARATO, M. As Revoluções do Capitalismo. Rio de Janeiro: Civilização Brasileira, 2006.

Marx, Karl. Grundrisse: Manuscritos econômicos de 1857-1858, Esboços da crítica da economia política. São Paulo: Boitempo, 2011.

NEGRI, Antônio. Marx além de Marx: ciência da crise e da subversão. Caderno de trabalho sobre os Grundrisse. São Paulo: Autonomia Literária, 2016.

NEGRI, A.; COCCO, G. Global: biopoder e luta em uma América Latina globalizada.Trad. Eliana Aguiar. Rio de Janeiro: Record, 2005.

\footnotetext{
${ }^{1}$ Professor Adjunto do Departamento de Fundamentos Sócio-Filosóficos da Educação - UFPE. Doutor em Educação UNESP/Marília. E-mail: raphael.guazzelli@ufpe.br. ORCID: http://orcid.org/0000-0003-2058-6478.

2 Doutorando em Educação (UNICAMP), Mestre em História e Filosofia da Educação (UNICAMP) e Licenciado em História. E-mail: mailto:camargo.andre.campos@gmail.comORCID: http://orcid.org/0000-0002-5148-3781.

Revista Tópicos Educacionais, Pernambuco, v. 27, n. 02, p. a, 2021. ISSN: 2448-0215.

https://periodicos.ufpe.br/revistas/topicoseducacionais/index

DOI: https://doi.org/10.51359/2448-0215.2021.252697
} 